\title{
AN OLD PROCEDURE WITH NEW SOLUTIONS FOR THE RULE OF LAW CRISIS
}

\author{
FRANZISKA-MARIE LAURA HILPERT*
}

\begin{abstract}
While commentators for the past years, have highlighted that there is no effective enforcement mechanism after accession for the values of the European Union which are enshrined in Article 2 TEU, the Juncker Commission has announced in 2017 that it will be 'bigger and more ambitious on big things, and smaller and more modest on small things' thus applying a more strategic approach to enforcement in terms of handling infringements. This Article thus analyses two cases brought by the Juncker Commission after 2017 and on their bases seeks to show that the infringement procedure, when applied strategically, is and remains an effective enforcement mechanism even for the values enshrined in Article 2 TEU in the 'rule of law crisis'. Thus, by way of analysis of the case C-619/18 Commission v Poland and its comparison with similar cases which have not been as effective, it is shown how the infringement procedure can prevent the enforcement of the most controversial provisions regarding the judiciary in Hungary and Poland and ensure the separation of powers, which is essential for the rule of law. Moreover, by comparison of the Commission's request and the decision of the Court of Justice of the European Union in C-235/17 Commission v Hungary it is shown how the Charter could become a significant legal instrument in the Commissions infringement policy towards Member States that are undermining fundamental rights and the rule of law. This Article thereby aims to contribute to the discussion on how to effectively enforce the values of the EU enshrined in Article 2 TEU through an existing enforcement mechanism.
\end{abstract}

\section{1}

\section{INTRODUCTION}

Europe's rule of law crisis has worsened over the past years and remains the most urgent issue that needs to be solved within the European Union. ${ }^{1}$ Unfortunately, most efforts taken by the European Institutions towards safeguarding the rule of law, fundamental rights and democracy in Poland and Hungary, have been too late, such as triggering Article 7(1) TEU, ${ }^{2}$ or proven to be ineffective, ${ }^{3}$ a worrying example for this, is the case C-286/12 Commission v Hungary. ${ }^{4}$ Thus so far the Commission's intervention has been ineffective towards ensuring

\footnotetext{
* Trainee at the European Patent Office, Dept. Institutional and general legal matters. The author would like to thank Xavier Groussot for his support and input throughout the writing process as well as for the time that he spent discussing and reviewing the article.

${ }^{1}$ Matthias Schmidt and Piotr Bogdanowicz, 'The infringement procedure in the rule of law crisis: How to make effective use of Article 258 TFEU' (2018) 55 Common Market Law Review 1061, 1061.

2 Laurent Pech and Kim Lane Scheppele, 'Poland and the European Commission, Part I: A Dialogue of the Deaf?' (Verfassungsblog, 3 January 2017) < https://verfassungsblog.de/poland-and-the-european-commissionpart-i-a-dialogue-of-the-deaf/> accessed 26 March 2019.

${ }^{3}$ Dimitry Kochenov, 'Biting Intergovernmentalism: The Case for the Reinvention of Article 259 TFEU to Make It a Viable Rule of Law Enforcement Tool' (2015) 7 Hague Journal on the Rule of Law 153.

${ }^{4}$ In Case C-286/12 European Commission v Hungary EU:C:2012:687 the Commission successfully brought infringement proceedings on the grounds of age discrimination against Hungary's legislation that radically lowered the retirement age of Hungarian judges. But the threat to the independence of the judiciary could not
} 
the protection of democracy, the rule of law and fundamental rights. ${ }^{5}$ This is why especially the Commission, as the 'guardian of the Treaties', ${ }^{6}$ who should ensure not only that the acquis but also that the fundamental values on which the EU is founded are observed, ${ }^{7}$ has received much criticism over the past years. ${ }^{8}$

Commentators, however, have not only criticised the Commission but also at the same time highlighted weaknesses and limitations regarding Article 258 TFEU when dealing with breaches of the rule of law, fundamental rights and other values enshrined in Article 2 TEU. The criticism regarding the effectiveness of the Infringement procedure under Article 258 TFEU has encouraged commentators to put forward many proposals to enhance rule of law enforcement. Besides the 'Reverse Solange' approach, ${ }^{10}$ the proposal for a 'Copenhagen Commission', ${ }^{11}$ 'the Fundamental Rights Agency', ${ }^{12}$ and the 'Horizontal Solange' ${ }^{13}$ concept the 'systematic infringement actions ${ }^{14}$ proposed by Scheppele, has received much attention. ${ }^{15}$ While some of these proposals built upon existing legal bases and merely require a reinterpretation of existing tools (such as 'the systematic infringement action') others require Treaty or legislative amendments (eg the proposal to amend Article 51 of the Charter) or the creation of new institutions (eg 'the Copenhagen Commission'). ${ }^{16}$ Thus while these approaches are innovative and some more likely to be effective than others, especially in the

be averted as the judges affected by the legislation have already been retired and were not reinstated in their previous positions; (Dimitry Kochenov and Laurent Pech, 'Upholding the Rule of Law in the EU: On the Commission's 'Pre-Article 7 Procedure' as a Timid Step in the Right Direction' (2015) 24 Robert Schuman Centre for Advanced Studies Research Paper 512 4).

${ }^{5}$ Kochenov (n 3) 166.

${ }^{6}$ Dimitry Kochenov and Laurent Pech, 'Better Late than Never? On the Commission's Rule of Law Framework and its First Activation' (2016) 54 Journal of Common Market Studies 1062, 1062.

${ }^{7}$ Kochenov and Pech, 'Better Late than Never? On the Commission's Rule of Law Framework and its First Activation'(n 6) 1062.

${ }^{8}$ Michael Blauberger and R. Daniel Kelemen, 'Can courts rescue national democracy? Judicial safeguards against democratic backsliding in the EU’ (2017) 24 Journal of European Public Policy 321.

${ }_{9}$ Blauberger and Kelemen (n 8) 323.

10 Armin Von Bogdandy and others, 'Reverse Solange_-Protecting the Essence of Fundamental Rights against EU Member States’ (2012) 49 Common Market Law Review 489.

${ }^{11}$ Jan-Werner Müller, 'Should the EU Protect Democracy and the Rule of Law inside Member States?' (2015) 21 European Law Journal 141.

12 Gabriel N. Toggenburg and Jonas Grimheden, 'Upholding Shared Values in the EU: What Role for the EU Agency for Fundamental Rights?' (2016) 54 Journal of Common Market Studies 1093.

13 Iris Canor, 'My brother's keeper? Horizontal solange: "An ever closer distrust among the peoples of Europe”" (2013) 50 Common Market Law Review 383.

${ }^{14} \mathrm{Kim}$ Lane Scheppele, 'Enforcing the basic principles of EU law through systemic infringement actions' in Carlos Closa and Dimitry Kochenov (eds), Reinforcing Rule of Law Oversight in the European Union (Cambridge University Press 2016).

${ }^{15}$ Carlos Closa, Dimitry Kochenov and J.H.H. Weiler, 'Reinforcing Rule of Law Oversight in the European Union' (2014) 25 Robert Schuman Centre for Advanced Studies Research Paper-11; Scheppele (n 14) 105132; Blauberger and Kelemen (n 8) 324, 330; Schmidt and Bogdanowicz (n 1) 1066-1069.

${ }_{16}$ Closa, Kochenov and Weiler (n. 15) 10; Daniel Hegedüs, 'Is there a New Impetus or a Political Paralysis regarding the protection of the EU's Fundamental Values? A comparative analysis of policy proposals and adopted procedures from the Copenhagen Commission proposal to the Rule of Law Initiative of the European Commission' (Friedrich-Naumann-Stiftung, 2015)

<https://www.academia.edu/15151337/Is_there_a_New_Impetus_or_a_Political_Paralysis_regarding_the_ protection_of_the_EU_s_Fundamental_Values_A_comparative_analysis_of_policy_proposals_and_adopted _procedures_from_the_Copenhagen_Commission_proposal_to_the_Rule_of_Law_Initiative_of_the_Europ ean_Commission> accessed 31 March 2019. 
current context of urgency, ${ }^{17}$ they are still dependent on the willingness of the EU institutions and the Member States to use them.

Due to the fact, that the Commission announced in 2017 that it will be using the infringement procedure more strategic and more efficient in line with the Juncker Commission's commitment to be 'bigger and more ambitious on big things, and smaller and more modest on small things ${ }^{18}$ this Article will not propose that there is need for a new instrument. In the contrary, it is argued that the infringement procedure when applied strategically is and remains an effective enforcement mechanism which provides a solution to existing problems, even in the 'rule of law crisis'. In this regard it shall be shown how the Commission has found new ways to use, the traditional and the best-explored enforcement mechanism, ${ }^{19}$ the infringement procedure, effectively in order to address Member States failure to comply with fundamental rights and the rule of law. Concretely two ways in which the Commission is using the infringement procedure strategically and possibly also more effectively in regard to the rule of law have been identified and will be analysed. First exemplified on the basis of C-619/18 Commission v Poland ${ }^{20}$ it will be shown how the infringement procedure can prevent the enforcement of the most controversial provisions regarding the judiciary in Hungary and Poland, and second exemplified by C-235/17 Commission v Hungary ${ }^{21}$ it will be shown how the Charter could become a significant legal instrument in the Commissions infringement policy towards Member States that are undermining fundamental rights and the rule of law. Due to the fact that the cases are dealing with different issues related to the rule of law crisis, each case and thus approach related to the infringement procedure will be addressed separately. Section II will therefore deal with case C-619/18 Commission v Poland while Section III deals with case C-235/17 Commission v Hungary. Section IV is the conclusion.

\section{Protecting judicial independence - C-619/18 Commission V POLAND}

The Rule of law, as a common value of the EU as enshrined in Article 2 TEU, is a constitutional principle with both formal and substantive components, these include: legality, legal certainty, independent and impartial courts, effective judicial review including respect for fundamental rights, and equality before the law. ${ }^{22}$ In Poland the 'rule of law crisis' concerns mainly attacks on the national judiciary. ${ }^{23}$ The Polish Government of the Law and Justice Party (Prawo i Sprawiedliwość, PiS), has already successfully impaired the

\footnotetext{
${ }^{17}$ For a comparative analyses, see eg Dimitry Kochenov, 'On Policing Article 2 TEU Compliance - Reverse Solange and Systemic Infringements Analyzed ' (2013) 33 Polish Yearbook of International Law 145; Closa, Kochenov and Weiler (n 15) 15-20.

${ }^{18}$ European Commission, 'EU law: Better results through better application (Communication)' (OJ 2017 C 18/10, 19 January 2017).

${ }^{19}$ Blauberger and Kelemen (n 8) 323.

${ }^{20}$ Case C-619/18 European Commission v Republic of Poland EU:C:2019:531.

${ }^{21}$ Case C-235/17 European Commission v Hungary EU:C:2019:432.

22 European Commission, 'A new EU Framework to strengthen the Rule of Law (Communication)' (COM(2014) 158 final, 2014).

23 Matteo Bonelli and Monica Claes, 'Judicial serendipity: how Portuguese judges came to the rescue of the Polish judiciary: ECJ 27 February 2018, Case C-64/16, Associação Sindical dos Juízes Portugueses’ (2018) 14 European Constitutional Law Review 622623.
} 
Constitutional Court in Poland, and it recently attempted to continue this impairment with the Ordinary Courts by introducing its Law of 12 July 2017 (amending the Law on the Organisation of Ordinary Courts) and with the Supreme Court by introducing its law of $8^{\text {th }}$ December 2017 (lowering the retirement age of Supreme Court judges to 65 years, also for those who were appointed before the date of entry). ${ }^{24}$

While the Infringement Procedure, Article 258 TFEU, empowers the Commission to bring matters before the CJEU where it considers that a Member State has failed to fulfil an obligation under the Treaties, including the values enshrined in Article 2 TEU, ${ }^{25}$ it was believed for a long time that the substantively vague, political and programmatic provision of Article 2 TEU does not create obligations that could be enforced. ${ }^{26}$ Due to this widely spread understanding of Article 2 TEU, situations that pose a systematic threat to the rule of law, such as in in C-286/12 Commission v Hungary, could not be addressed as a breach of an obligation under the Treaties when they did not infringe a specific and concrete provision of EU law at the same time as the rule of law. ${ }^{27}$ In C-286/12 Commission v Hungary, the absence of a concrete provision over independence and impartiality of the national judiciary, has led to ineffective protection of the rule of law, as the fall back on the principle of nondiscrimination on the ground of age has led to compensation of the Judges instead of restoration into their former positions. ${ }^{28} \mathrm{~A}$ similar problematic seemed to arise from case $\mathrm{C}$ 192/18 Commission v Republic of Poland ${ }^{29}$, addressing the concerns of the Commission with the Law of 12 July 2017 (amending the Law on the Organisation of Ordinary Courts), thus leaving the most controversial measures on the judiciary planned by Poland not enforceable through Article 258 TFEU. ${ }^{30}$

The CJEU in last year's Grand Chamber Judgement in Associação Sindical dos Juizęes Portugueses $^{31}$ ensured, however, that the most controversial measures on the judiciary planned by Poland can be enforceable. ${ }^{32}$ The CJEU by answering the question whether the temporary reductions of remuneration of the judges infringed the principle of judicial independence enshrined in Article 19(1) TEU and Article 47 of the Charter, ${ }^{33}$ referred to it by the Supreme Administrative Court of Portugal, where an association of Portuguese magistrates brought

${ }^{24}$ Court of Justice of the European Union, Advocate General's Opinion in Case C-619/18 Commission v Poland (Press Release No 48/19, Luxembourg 11 April 2019); Schmidt and Bogdanowicz (n 1) 1061.

25 Petra Bárd and others, 'An EU mechanism on democracy, the rule of law and fundamental rights Annex II - Assessing the need and possibilities for the establishment of an EU scoreboard on democracy, the rule of law and fundamental rights' (European Parliamentary Research Service, 2016).

${ }^{26}$ Müller; Dimitry Kochenov and Laurent Pech, 'Monitoring and Enforcement of the Rule of Law in the EU: Rhetoric and Reality' (2015) 11 European Constitutional Law Review 512; Christophe Hillion, 'Overseeing the Rule of Law in the EU: Legal Mandate and Means' in Carlos Closa and Dimitry Kochenov (eds), Reinforcing rule of law oversight in the European Union (Cambridge University Press 2016); Schmidt and Bogdanowicz (n 1) 1080.

${ }^{27}$ European Commission, 'A new EU Framework to strengthen the Rule of Law (Communication)' (n 22) 5; Kochenov and Pech, 'Upholding the Rule of Law in the EU: On the Commission's 'Pre-Article 7 Procedure' as a Timid Step in the Right Direction' (n 4) 4; Commission v Hungary (n 4).

${ }^{28}$ Kochenov and Pech, 'Upholding the Rule of Law in the EU: On the Commission's 'Pre-Article 7

Procedure' as a Timid Step in the Right Direction' (n 4$) 4$.

${ }^{29}$ Case C-192/18 European Commission v Republic of Poland, Action brought on 15 March 2018.

${ }^{30}$ Maciej Taborowski, 'CJEU Opens the Door for the Commission to Reconsider Charges against Poland' (Verfassungsblog, 13 March 2018) < https://verfassungsblog.de/cjeu-opens-the-door-for-the-commission-toreconsider-charges-against-poland/> accessed 3 April 2019.

${ }^{31}$ Case C-64/16 Associação Sindical dos Juires Portugueses v Tribunal de Contas EU:C:2018:117.

32 Bonelli and Claes (n 23) 628; Case C-64/16 Portuguese Judges EU:C:2018:117.

33 Portuguese Judges (n 32) para 13. 
an action for annulment against the implementation of administrative measures which reduced their remuneration of the judges of the Court of Auditors, ${ }^{34}$ held that 'Article 19 TEU, which gives concrete expression to the value of the rule of law stated in Article 2 TEU, entrusts the responsibility for ensuring judicial review in the EU legal order not only to the Court of Justice but also to national courts and tribunals'. ${ }^{35}$ Thus the CJEU established that, Member States are under an obligation, contained in primary EU law (Article 19(1)(2) TEU), to ensure that their courts and judges meet the requirements of effective judicial protection, independence being an essential requirement thereof, ${ }^{36}$ while at the same time affirming that Article $2 \mathrm{TEU}$ is a legally binding provision which is obligatory and can create concrete duties on Member States. ${ }^{37}$ The judgement of the CJEU in Portuguese Judges can therefore be seen as a signal to the Commission to use Article 19(1)(2) TEU directly in infringement proceedings where a measure undermines the independence of the national judiciary as part of the EU judiciary. ${ }^{38}$

With sending a Letter of Formal Notice to Poland, the Commission on $2^{\text {nd }}$ October 2018 launched infringement proceedings based on Article 19(1)(2) TEU, read in conjunction with Article 47 of the Charter, ${ }^{39}$ concerning the Polish law on the Supreme Court which lowered the retirement age for Supreme Court judges, also for those who were appointed before the date of entry, to 65 years, thus, forcing possibly 27 out of 72 Supreme Court judges into retirement. ${ }^{40}$ Case C-619/18 Commission v Poland thus presented the Court 'with the opportunity to rule, for the first time within the context of a direct action for infringement under Article 258 TFEU, on the compatibility of certain measures taken by a Member State concerning the organisation of its judicial system with the standards set down in Article 19(1)(2) TEU, combined with Article 47 of the Charter, for ensuring respect for the rule of law in the Union legal order, ${ }^{41}$ Thus this case provides the CJEU with the opportunity to address the topic of judicial independence, as the Commission contests that the national measure lowering the retirement age infringes the principle of security of tenure (irremovability) of judges, and that the powers of the President of Poland to prolong the mandate of the Supreme Court judges, infringes the principle of judicial independence. ${ }^{42}$

34 ibid, para 12; Michał Krajewski, 'Associação Sindical dos Juízes Portugueses: The Court of Justice and Athena’s Dilemma’ (2018) 3 European Papers A journal on law and integration 395.

35 Portuguese Judges (n 32), para 32.

${ }^{36}$ Bonelli and Claes (n 23) 623; Alessandra Silveira and Sophie Perez Fernandes, 'A Union based on the rule of law beyond the scope of EU law - the guarantees essential to judicial independence in Associação Sindical dos Juízes Portugueses' (UNIO EU Law Journal, 3 April 2018)

$<$ https://officialblogofunio.com/2018/04/03/a-union-based-on-the-rule-of-law-beyond-the-scope-of-eulaw-the-guarantees-essential-to-judicial-independence-in-associacao-sindical-dos-juizes-portugueses / > accessed 5 April 2019.

${ }^{37}$ Xavier Groussot and Johan Lindholm, 'General Principles: Taking Rights Seriously and Waving the Ruleof-Law Stick in the European Union ' in K. Ziegler et al (ed), Constructing Legal Orders in Europe: General Principles of EU Law (Edward Elgar Forthcoming 2019) 10; Dimitry Konchev and Marcus Klamert, 'Article 2 TEU' in Manuel Kellerbauer, Marcus Klamert and Jonathan Tomkin (eds), The Treaties and the Charter of Fundamental Rights - A Commentary (Oxford University Press 2019) 6.

38 Taborowski (n 30).

${ }^{39}$ European Commission, 'Rule of Law: Commission launches infringement procedure to protect the independence of the Polish Supreme Court' (European Commission Press Release Database, 2 July 2018) $<$ https://europa.eu/rapid/press-release_IP-18-4341_en.htm> accessed 18 September 2019.

${ }^{40}$ European Commission (n 39); Court of Justice of the European Union (n 24).

${ }^{41}$ Case C-619/18 European Commission v Republic of Poland EU:C:2019:325, Opinion of AG Tanchev, para 2.

${ }^{42}$ Case C-619/18 European Commission v Republic of Poland, Action brought on 2 October 2018; Jakub Jaraczewski, 'Age is the limit? Background of the CJEU case C-619/18 Commission v Poland' 
Respectively it provides the opportunity to address whether Poland has breached the rule of law and the relationship between Article 258 TFEU and Article 7 TEU as well as to clarify the material scope of Article 19(1)(2) TEU. ${ }^{43}$ Before considering these aspects and their meaning and consequences for the case and an effective rule of law enforcement in Europe, five events need to be highlighted that followed the application by the Commission for infringement proceedings in C-619/18 Commission v Poland.

First, with the application of the infringement procedure, the Commission also applied for interim measures pursuant to Article 279 TFEU and Article 160(2) and (7) of the Rules of Procedure of the Court of Justice. ${ }^{44}$ The Vice-President of the Court, on the request that it be decided inaudita altera parte, on $19^{\text {th }}$ October 2018 provisionally granted the interim measures ${ }^{45}$ and on $17^{\text {th }}$ December 2018 the CJEU sitting in Grand Chamber, after hearing the observations of Poland, confirmed his decision. ${ }^{46}$ Second, on $15^{\text {th }}$ November 2018, the President of the Court ordered, following the request of the Commission, ${ }^{47}$ that case C-619/18 Commission v Poland shall be determined pursuant to the expedited procedure. ${ }^{48}$ Third, on $21^{\text {st }}$ November 2018, the Sejm (lower house) approved an amendment of the Law of the Supreme Court; the Commission, however, did not withdraw the infringement action. ${ }^{49}$ Fourth, Advocate General Tanchev delivered his opinion on $11^{\text {th }}$ April 2019. ${ }^{50}$ Most noteworthy, the Advocate General, first rebutted the arguments concerning admissibility, recalling that in order to determine whether a Member State has failed to fulfil its obligations under Article 258 TFEU, it is not the situation at the time of the judgement given that matters but the situation on $14^{\text {th }}$ September 2018, as this is the end date of the period laid down in the reasoned opinion. ${ }^{51}$ Since the amendment entered into force only on $1^{\text {st }}$ January 2019 the Advocate General found that the Law passed on $21^{\text {st }}$ November 2018 does not eliminate the need for the CJEU to rule on this case. ${ }^{52}$ Second, the Advocate General held, that the engagement of Article 7(1) TEU mechanism does not preclude the infringement actions. ${ }^{53}$ Third, the Advocate General subsequently considers that a separate assessment of Article 19(1)(2) TEU and Article 47 of the Charter is required..$^{54}$ In consequence, the Advocate General found that the complaints are well founded in so far as they are based on Article

(Verfassungsblog, 28 May 2019) < https://verfassungsblog.de/age-is-the-limit-background-of-the-cjeu-case-c619-18-commission-v-poland/> accessed 20 August 2019.

43 Jaraczewski (n 42).

${ }_{44}$ European Commission, 'Rule of Law: European Commission refers Poland to the European Court of Justice to protect the independence of the Polish Supreme Court' (European Commission Press Release Database, 24 September 2018) < http://europa.eu/rapid/press-release_IP-18-5830_en.htm> accessed 18 September 2019.

${ }^{45}$ Case C-619/18 R European Commission v Republic of Poland EU:C:2018:852, Order of the Vice-President of the Court, para 26.

${ }^{46}$ Case C-619/18 R European Commission v Republic of Poland EU:C:2018:1021, Order of the Court (Grand Chamber), para 118.

${ }^{47}$ European Commission, 'Rule of Law: European Commission refers Poland to the European Court of Justice to protect the independence of the Polish Supreme Court' (n 44).

48 Case C-619/18 European Commission v Republic of Poland EU:C:2018:910, Order of the President of the Court

(Expedited procedure).

49 Opinion of AG Tanchev (n 41), para 25.

50 ibid.

51 ibid, para 44.

$52 \mathrm{ibid}$, paras 46-47.

53 ibid, paras 48-51.

$54 \mathrm{ibid}$, para 54. 
19(1)(2) TEU but that they are not admissible in so far as they are based on Article 47 of the Charter, due to the fact that the Commission has not provided any arguments to illustrate that Poland has implemented EU law in the sense of Article 51(1) of the Charter. ${ }^{55}$ Thus, the Advocate General proposed that the Court should declare that Poland, by passing the new Law on the Supreme Court, that lowered the retirement age for Supreme Court judges to 65 years and which also granted the President of the Republic the discretion to prolong the time before retirement, failed to fulfil its obligations under Article 19(1)(2) TEU to 'provide remedies sufficient to ensure effective legal protection in the fields covered by Union law'. ${ }^{56}$

Last, on 24 $4^{\text {th }}$ June 2019 the CJEU sitting in Grand Chamber delivered its judgment in case C-619/18. The Court, following the Opinion of the Advocate General, found, that the Republic of Poland has failed to fulfil its obligations under Article 19(1)(2) TEU on the one hand by providing that the measure consisting in lowering the retirement age of the judges of the Sad Najwyziszy (Supreme Court, Poland) is to apply to judges in post who were appointed to that court before 3 April 2018 and on the other hand by granting the President of the Republic the discretion to extend the period of judicial activity of judges of that court beyond the newly fixed retirement age. ${ }^{57}$

In regard to the question of admissibility, the Court, siding with and providing similar arguments then the Advocate General, found the case to be admissible. ${ }^{58}$ Thereafter, the Court continued to analyse the applicability and the scope of Article 19(1)(2) TEU. On this subject the Court held that the national rules called into question by the Commission in its action may be reviewed in the light of Article 19(1)(2) TEU, ${ }^{59}$ and that Article 19(1)(2) TEU refers to 'the fields covered by Union law', irrespective of whether the Member States are implementing Union law within the meaning of Article 51(1) of the Charter. ${ }^{60}$ The Court also confirmed thereby, that Article 19(1) TEU requires Member States to provide remedies that are sufficient to ensure effective legal protection, within the meaning in particular of Article 47 of the Charter, in the fields covered by EU law. ${ }^{61}$

Regarding the first complaint, ${ }^{62}$ the Court, recalling what it has previously stated namely that Article 19(1)(2) TEU requires that the Courts must be independent, recalled not only its well established case law on independence previously developed in Wilson ${ }^{63}$, but also to its recent statements on independence and impartiality in paragraph 67 of C-216/18 PPU Minister for Justice and Equality (Deficiencies in the system of justice) ${ }^{64}$, thus linking the requirement of independence established in the context of assessing the admissibility of references with the requirement that are necessary to safeguards the rights under Article 47 and 48 of the Charter. ${ }^{65}$ The Court found that the reform which was being challenged, raised reasonable concerns as regards compliance with the principle of the irremovability of judges, which

\footnotetext{
55 ibid, paras 61-67.

56 ibid, para 99.

${ }^{57}$ Commission v Poland (n 20), para 126.

58 Opinion of AG Tanchev (n 41), para 44.

59 Commission v Poland (n 20), para 59.

${ }^{60} \mathrm{ibid}$, paras 50-54.

61 ibid, paras 50-54.

62 The first complaint is that the lowering the retirement age of Supreme Court judges violates the principle of irremovability of judges (Commission v Poland (n 20), paras 25-26).

${ }^{63}$ Case C-506/04 Grabam J. Wilson v Ordre des avocats du barreau de Luxembourg EU:C:2006:587, para 53.

${ }^{64}$ Case C-216/18 PPU Minister for Justice and Equality, LM EU:C:2018:586, paras 64-67.

${ }^{65}$ Commission v Poland (n 20), paras 71-77.
} 
requires in particular, that judges may remain in post provided that they have not reached the obligatory retirement age or until the expiry of their mandate, where that mandate is for a fixed term. ${ }^{66}$ In order to come to the conclusion that the measure lowering the retirement age of the Supreme Court Judges is not justified by a legitimate objective, the Court not only held that the reform by Poland raises doubts as to its legitimate objectives, that Poland has failed to show that the measure constitutes an appropriate means for the purpose of the objective, that the measure is not satisfying the proportionality requirement, but also, similar to the Advocate General, distinguished the circumstances of the case from those in Portuguese Judges. ${ }^{67}$ Finding that it does not follow from the judgement in Portuguese Judges that provisions applicable to judges related to general policies are automatically contrary to the principle of judicial independence, but rather that this depends on the circumstances of the specific case and that the effects of the limited and temporary salary reduction are in no way comparable to the effects of the measure of lowering the retirement age of the judges. ${ }^{68}$

In regard to the second complaint, ${ }^{69}$ the Court, referring to its previously cited case law, ${ }^{70}$ stated, that the concept of independence and impartiality presuppose that the body concerned exercises its functions wholly autonomously, without being subject to any hierarchical constraint or subordinated to any other body and without taking orders or instructions from any source whatsoever, thus being protected against external interventions or pressure liable to impair the independent judgment of its members and to influence their decisions'. ${ }^{71}$ Based thereof, the Court finds, after a detailed analyses of the procedure, that the contested measures violate the requirements of judicial independence, dismissing Poland's arguments based on the laws of the other Member States and the appointment of Judges at the Court of Justice, as on the one hand Poland, cannot rely on the possible infringement of EU law by another Member State and on the other hand, that the conditions set under the Treaties cannot modify the scope of obligations imposed on the Member States. ${ }^{72}$

\subsection{The Significance of C-619/18 Commission v Poland}

After having addressed the important events following the application of the Commission it will be explained why this judgement of the Court will have precedent-setting character and a fundamental importance for the protection of the rule of law. In this regard three aspects shall be addressed. First, the fact that the judgment undoubtedly clarifies that the Commission can bring infringement proceedings under Article 258 TFEU even where Article 7(1) TEU has been initiated. Second, that the Commission can rely on Article 19(1)(2) TEU autonomously in infringement proceedings while further substantiating the

\footnotetext{
66 ibid, paras 76-78.

${ }^{67}$ Commission v Poland (n 20) paras 92-93; in comparison to Opinion of AG Tanchev (n 41) paras 74-81.

${ }^{68}$ Commission v Poland (n 20) paras 92-93; see for a similar assessment see Opinion of AG Tanchev (n 41), paras 74-81.

${ }_{69}$ The second complaint by the Commission is that the President of the Republic's discretion, to extend the active mandate of Supreme Court judges upon reaching the lowered retirement age allows him to exert influence on the Supreme Court and its judges, violates the principle of judicial independence (Commission v Poland (n 20), para 84).

${ }^{70}$ Wilson (n 63), para 51; Portuguese Judges (n 32), para 44.

${ }^{71}$ Commission v Poland (n 20) para 108.

72 ibid, paras 120-124.
} 
interpretation of Article 19(1)(2) TEU through Article 47 of the Charter and third, most importantly, that the judgment by applying a strong rule of law didactic not only shows the national governments that the organisation of the national judiciary is not a purely domestic matter which the Court is willing to protect but also that the independence of the judiciary, and the effective judicial protection and ultimately the rule of law are essential values to European Union that are enforceable.

\section{1 [a] Relationship between Article 258 and Article 7 TEU}

First, even though not specifically addressed by the Court, the judgement clarifies the relationship between Article 258 TFEU and Article 7 TEU. This is important as it resolves any remaining discussion on the applicability of Article 258 TFEU where Article 7(1) TEU has been triggered. ${ }^{73}$ This is a significant aspect, in relation to future cases brought by the Commission under Article 258 TFEU against Poland and Hungary where Article 7(1) TEU has been invoked, as the Commission might otherwise not bring further infringement proceedings where these are unlikely to be effective due to fear of its credibility. ${ }^{74}$ This clarity regarding the relationship between Article 258 TFEU and Article 7 TEU thus strengthens the Rule of Law Framework as it adds the infringement procedure as one of the best explored and successful mechanisms to the tools the Commission can use against Member States that are failing to fulfil their obligations while also breaching the rule of law and which, in contrast to Article 7(1) TEU, can further lead to financial consequences. ${ }^{75}$

\section{1 [b] The Material Scope of Article 19(1)(2) TEU}

Second, this judgement is noteworthy because it clarified the applicability and the material scope of Article 19(1)(2) TEU and its relationship with Article 47 of the Charter. ${ }^{76}$ Three solutions were possible in this regard. Firstly, a combined application of Article 19(1)(2) TEU and Article 47 of the Charter in the absence of assessment under Article 51(1) of the Charter (which would mean that Article 47 of the Charter and Article 19(1)(2) TEU have the same scope of application). Secondly, the Court had the option to follow the Opinion of the Advocate General, who found that a separate assessment of the material scope of Article 19(1) TEU and Article 47 of the Charter is required while avoiding Article 47 of the Charter completely, instead the Advocate General draw on the principles of EU law stemming from the case law of the ECtHR and guidelines issued by European and international bodies when interpreting the meaning of Article 19(1)(2) TEU. ${ }^{77}$ Or, thirdly, the Court could have in line with the view of the Commission, ${ }^{78}$ required a separate assessment of the material scope of

\footnotetext{
73 Piotr Bogdanowicz, 'Three Steps Ahead, One Step Aside: The AG's Opinion in the Commission v. Poland Case' (Verfassungsblog, 11 April 2019) < https://verfassungsblog.de/three-steps-ahead-one-step-aside-the-agsopinion-in-the-commission-v-poland-case/> accessed 18 April 2019 .

${ }^{74}$ Heather Grabbe, 'Six Lessons of Enlargement Ten Years On: The EU's Transformative Power in

Retrospect and Prospect' (2014) 52 JCMS: Journal of Common Market Studies 40.

${ }_{75}$ Blauberger and Kelemen (n 8) 323.

${ }^{76}$ Commission v Poland (n 20), paras 42-59.

77 Opinion of AG Tanchev (n 41), para 54, 71.

$78 \mathrm{ibid}$, para 26; see also in regard to the use of Article 47 of the Charter in connection with Article 19 TEU the argument reteirated from the hearing of the Ordinary Courts case in Femke Gremmelprez, 'Does Poland infringe the principle of effective judicial protection? Recent developments in the CJEU' (EU Law Analysis,
} 
Article 19(1)(2) TEU and Article 47 of the Charter while using Article 47 of the Charter as an interpretative tool of the substance of Article 19(1)(2) TEU. ${ }^{79}$ This would mean that Article 19(1)(2) TEU constitutes an autonomous standard for ensuring effective judicial protection, including judicial independence as interpreted by the second subparagraph of Article 47 of the Charter.

Some commentators ${ }^{80}$ hoped for the first possibility, a combined application of Article 19(1)(2) TEU and Article 47 of the Charter in the absence of assessment under Article 51(1) of the Charter, as this could lead to a wider application of the Charter and potentially make the EU become a 'community of fundamental rights' which would in turn strengthen the respect for the rule of law. ${ }^{81}$ However, this solution, to use the words of Advocate General Tanchev, would 'undermine the current system of review of the compatibility of national measures with the Charter and open the door for Treaty provisions such as Article 19(1) TEU to be used as a "subterfuge" to circumvent the limits of the scope of application of the Charter as set out in Article 51(1) thereof ${ }^{82}$ Furthermore, this interpretation would not only be contrary to the wording and meaning of Article 51(1) of the Charter but also most likely be received as an unjustified competence creep by the CJEU, as this would intervene in Member States, where constitutional Courts consider it their 'sovereign' entitlement to ensure the protection of fundamental rights enshrined in the national constitution. ${ }^{83}$ Thus one could argue, that it was due to this expected controversy between the constitutional courts and the CJEU, which could due to the lack of legitimacy give grounds for attack to the parties with conflicting interests, as well as in the light of the findings of the Advocate General, that the Court chose to avoid this solution.

The Court, however, affirmed, what commentators have interpreted from Portuguese Judges $^{84}$, namely that the material scope of Article 19(1)(2) TEU requires an independent assessment from Article 47 of the Charter, as Article 19(1)(2) TEU applies unrelatedly of the Charter, while finding that 'Article 19(1)(2) TEU requires Member States to provide remedies that are sufficient to ensure effective legal protection, within the meaning in particular of Article 47 of the Charter. ${ }^{85}$ By aligning the substantive content of Article 19(1)(2) TEU and

15 April 2019) < https://eulawanalysis.blogspot.com/2019/04/does-poland-infringe-principle-of.html> accessed 21 April 2019..

79 Opinion of AG Tanchev (n 41), para 26.

${ }^{80}$ In this regard see eg: András Jakab, 'Application of the EU CFR by National Courts in Purely Domestic Cases' in András Jakab and Dimitry Kochenov (eds), The Enforcement of EU Law and Values: Ensuring Member States' Compliance (1 edn, Oxford University Press 2017) 252, 253; Von Bogdandy and others (n 10) 508 ff. 81 Jakab (n 80) 255.

82 Opinion of AG Tanchev (41), para 57.

83 Thomas Von Danwitz, 'The Rule of Law in the Recent Jurisprudence of the ECJ' in Werner Schroeder (ed), Strengthening the Rule of Law in Europe: From a Common Concept to Mechanisms of Implementation (1 edn, Hart Publishing 2016).

84 See for this interpretation of ASJP Judgement eg :Bonelli and Claes (n 23) 642; Krajewski (n 34) 397; Laurent Pech and Sébastien Platon, 'A. Court of Justice: Judicial independence under threat: The Court of Justice to the rescue in the ASJP case' (2018) 55 Common Market Law Review 1827; Koen Lenaerts, 'The Court of Justice and National Courts: a Dialogue Based on Mutual Trust and Judicial Independence' Speech at the Supreme Administrative Court of the Republic of Poland (Poland, 19 March 2018) < http:/ /www.acaeurope.eu/index.php/en/114-library> accessed 18 April 2019 7-8.

85 Commission v Poland (n 20), para 54; Similar to Portuguese Judges (n 32), paras 41-42 where the CJEU referred to CJEU judgements; Case C-685/15 Online Games Handels GmbH and Others v Landespolizeidirektion Oberösterreich EU:C:2017:452, para 60; Case C-403/16 Soufiane El Hassani v Minister Spraw Zagranicznych EU:C:2017:960, para 40; and in contrast to Opinion of AG Tanchev (n 41) para 71-72. 
Article 47 of the Charter, the Court was not only able to provide a stronger reasoning in the assessment under Article 19(1)(2) TEU than was possible for the Advocate General, without creating controversy about any new scopes of application of the charter, ${ }^{86}$ but also strengthened Article 19 TEU as it connected the principle of effective judicial protection to the fundamental right to an effective remedy under Article 47 of the Charter. ${ }^{87}$

\section{1 [c] Making the rule of law more enforceable}

Third, the Court used this judgement to elaborate further on the role and application of the rule of law its strong interrelationship with the Union judicial system and its connection to the EU legal order in general. In that manner the Court connected a variety of concepts of Union law, starting with Article $49 \mathrm{TEU}$, which entails the free and voluntary commitment to the values enshrined in Article 2 TEU by the States, ${ }^{88}$ the court held that this premise both justifies and entails the existence of Mutual Trust, and that the values, including the rule of law, will be recognised and respected. ${ }^{89}$ The Court than drew the attention to the importance of the autonomy and the specific characteristics of the EU legal order highlights the judicial system that was established in order to ensure the consistency and uniformity in the interpretation of EU law, which has as its keystone the preliminary ruling procedure..$^{00}$ Moreover, the Court recalls that it is apparent from the settled case law that the Union is based on the rule of law, which individuals have the right to challenge before the courts the legality of any decision or other national measure concerning the application to them of an EU act. ${ }^{91}$ The Court then states that Article 19 (1) TEU, which gives concrete expression to the value of the rule of law affirmed in Article 2 TEU, entrusts the responsibility for ensuring the full application of EU law in all Member States and judicial protection of the rights of individuals under that law to national courts and tribunals and to the Court of Justice. ${ }^{92}$

By connecting these concepts in the way, the Court did it not only highlighted the importance of the rule of law as a value enshrined in Article 2 TEU but at the same time transforms the rule of law into an enforceable and invokable right, this transformation being incited through Article 19 TEU. ${ }^{93}$ The judgement further confirms that that Member States have a duty under Union law, which is connected to the rule of law, to provide effective legal protection including judicial independence. ${ }^{94}$ The Court also affirmed that all Article 267 Courts come under the protection of the Court of Justice, thus furthering the effectiveness of the EU legal order. ${ }^{95}$

\footnotetext{
86 See in this regard:Bonelli and Claes (n 23) 637; Portuguese Judges (n 32), para 41.

87 Groussot and Lindholm (n 37) 20.

88 Commission v Poland (n 20), para 42.

89 ibid, para 43.

90 ibid, paras 44-45.

91 ibid, para 46.

92 ibid, para 47.

${ }^{93}$ In a similar way: Groussot and Lindholm (n 37) 29.

94 Commission v Poland (n 20), paras 47-48.

$95 \mathrm{ibid}$, para 45 in addition with para 59.
} 


\subsection{Key Factors Which Make This Procedure Effective in the Rule of LaW Crisis}

So far, the significance of the judgment of the CJEU, and its importance for EU law as well as the rule of law has been established. Subsequently, it shall be highlighted why this Infringement Procedure was able to effectively protect the national judiciary and consequently the rule of law. It is argued, that the formula to success was the holistic approach to the infringement procedure by the Commission, more precisely that the Commission, drawing the right consequences from Portuguese Judges, based the procedure on Article 19(1)(2) TEU, asked for an expedited procedure and in addition requested interim measures. It follows, that this strategic use of the actions that are available to the Commission when using Article 258 TFEU make the Infringement Procedure effective, even in the rule of law crisis and without the construct of 'systematic infringement proceedings'.

As already described, relying on Article 19(1)(2) TEU in combination with Article 47 of the Charter makes it possible for the Commission and the CJEU to address concerns with the rule of law directly, which can help to prevent situations such as the one in C-286/12 Commission v Hungary where relying on a specific provisions of Directive 2000/78 did not eliminate the threat to the independence of the judiciary as the judges could be compensated instead of reinstated to their former positions. ${ }^{96}$

Better than hoping for reinstatement of the judges is, however, applying for interim measures (Article 279 TFEU) as well as requesting an expedited procedure (as referred to in Article 23a of the Statute of the Court of Justice of the European Union and Article 133 of the Rules of Procedure of the Court). In C-619/18 Commission v Poland the Commission requested both interim measures as well as the expedited procedure, as both measures were granted the interim measures effectively suspended the application of the law as well as ordered Poland to eliminate its effects, ${ }^{97}$ while the expedited procedure is the reason why the judgment has been given so quickly. ${ }^{98}$ Timing is important as always, since 'justice delayed is justice denied' also in the 'rule of law crisis'. ${ }^{99}$ This holds true especially, when the judiciary is under threat and the Commission has not applied for interim measures, such as in case C192/18 Commission v Republic of Poland on the Law on the Ordinary Courts. ${ }^{100}$ Due to the fact that the Commission did not request interim measures, many judges were forced into retirement, ${ }^{101}$ and since the Commission did also not request an expedited procedure, most of the changes will be invertible by the time the judgment will be passed as new presidents will have been appointed and the judges be replaced. ${ }^{102}$

\footnotetext{
${ }^{96}$ In analogy to Case C-286/12 Commission v Hungary (n 4); Kochenov and Pech, 'Upholding the Rule of Law in the EU: On the Commission's 'Pre-Article 7 Procedure' as a Timid Step in the Right Direction' 4.

97 Opinion of AG Tanchev (n 41), para 33.

${ }^{98}$ In accordance with Article 133 of the Consolidated version of the Rules of Procedure of the Court of Justice of 25 September 2012.

99 Schmidt and Bogdanowicz (n 1) 1097; William Penn, Some fruits of solitude, in reflections and maxims relating to the conduct of human life (2nd edn, Printed at London; and re-printed at Edinburgh : [s.n.], 1694); Hegedüs.

100 Case C-192/18 Commission v Poland, Action brought on 15 March 2018 ; Commission v Poland Order of the President of the Court (n 48); Commission v Poland Order of the Court (n 46).

${ }^{101}$ European Commission, 'Commission action on the Rule of Law in Poland: Questions \& Answers' (European Commission Press Release Database, 20 December 2017) < https://europa.eu/rapid/pressrelease_MEMO-17-5368_en.htm> accessed 18 September 2019; Schmidt and Bogdanowicz (n 1) 1079. 102 To this effect: European Commission, 'Commission action on the Rule of Law in Poland: Questions \& Answers' (n 101).
} 
This shows that only a holistic approach of these measures can promise success where the judiciary is under threat. It is, therefore, a positive development, that the Commission has launched another infringement procedure, based on Article 19(1) TEU read in connection with Article 47 of the Charter, against Poland regarding the new disciplinary regime for judges. ${ }^{103}$ If Poland does not reply within two months and further fails to discard the Commission's legal concerns it can be hoped that the Commission requests an expedited procedure as well as interim measures in order to have a chance to intervene effectively in the 'rule of law crisis'.

However, while we have seen that this approach is effective in the 'rule of law crisis' where the judiciary is under attack; scholarship has identified that in Hungary the 'rule of law crisis' is not only interfering with public institutions, such as the judiciary or ombudsman but also for example with the market economy. ${ }^{104}$ This is why in regards to the 'rule of law crisis' in Hungary, other approaches are necessary. As interference with the market economy can also be an interference with the rule of law, it will be addressed how the Infringement procedure could also be effective when dealing with Member States that are undermining the market economy and at the same time the rule of law. This approach is exemplified by case C-235/17 Commission v Hungary, where the Commission is trying to rely on the Charter as a sole basis for infringement proceedings, in order to address concerns on the rule of law and not only the market economy.

\section{Rule of Law Concerns And the Charter - C-235/17 COMMISSION V HUNGARY}

The 'rule of law crisis' in Hungary is not only concerning the judiciary but also interfering with the market economy, one of these interferences has been with the rights of cross-border investors in agricultural land. ${ }^{105}$ The law passed in 2013 by Hungary terminated, on $1^{\text {st }}$ May 2014, certain so-called 'usufruct rights' held by foreign and domestic investors in Hungary, without providing them with compensation. ${ }^{106}$ The Commission finds that this law deprived existing investors, due to the very short period provided between the publication of the legislation and its date of entry into force, of their acquired usufruct rights and the value of their investments. ${ }^{107}$ The Commission thus holds that this breaches the principle of legal certainty and the respect of the right to property under Article 17 of the Charter, as well as it breaches the principles of free movement of capital under Article 63 TFEU and freedom

\footnotetext{
103 European Commission, 'Rule of Law: European Commission launches infringement procedure to protect judges in Poland from political control' (European Commission Press Release Database, 3 April 2019)

<http://europa.eu/rapid/press-release_IP-19-1957_en.htm> accessed 18 September 2019.

104 Schmidt and Bogdanowicz (n 1) 1086-1087.

105 European Commission, 'Free movement of capital: Commission refers Hungary to the Court of Justice of the EU for failing to comply with EU rules on the rights of cross-border investors in agricultural land' (European Commission Press Release Database, 16 June 2016) < http://europa.eu/rapid/press-release_IP-162102_en.htm> accessed 18 September 2019.

${ }^{106}$ European Commission, 'Free movement of capital: Commission refers Hungary to the Court of Justice of the EU for failing to comply with EU rules on the rights of cross-border investors in agricultural land' (n 105).

107 European Commission, 'Free movement of capital: Commission refers Hungary to the Court of Justice of the EU for failing to comply with EU rules on the rights of cross-border investors in agricultural land' (n 105).
} 
of establishment under Article 49 TFEU. ${ }^{108}$ On this ground the Commission has decided to bring infringement proceedings against Hungary and asked the CJEU to declare that by adopting the legislation, which restricts certain usufruct rights, Hungary has failed to fulfil its obligations under Articles 49 and 63 of the TFEU and under Article 17 of the Charter. ${ }^{109}$

The law from 2013 on the rights of usufruct over agricultural land has also already been subject to Hungarian court proceedings, and subsequently led to a judgement of the CJEU in a preliminary ruling procedure in SEGRO. ${ }^{110}$ Even though, the preliminary ruling requests concern the interpretation of Articles 49 and 63 TFEU and of Articles 17 and 47 of the Charter the CJEU held that it was not necessary to examine the national legislation of concern in the light of the Charter in order to resolve the disputes in the main proceedings, as it found that Article 63 TEU must be interpreted as precluding legislation which restricts the free movement of capital. ${ }^{111}$ However, the Commission stressed that the Court should give its opinion on Articles 17 of the Charter in case C-235/17 Commission v Hungary, irrespective of the examination of the freedoms of movement. ${ }^{112}$ As the Advocate General Øe in paragraph 99 of his Opinion in C-235/17 Commission v Hungary has pointed out: such a review of the legislation of the Member States under the Charter in cases such as this would be necessary for the Commission in order to ensure respect for the rule of law in those states. ${ }^{113}$ It follows therefrom that the Commission is trying to argue for (as in SEGRO) an independent examination of Article 17 of the Charter in relation to the Hungarian legislation in order to ensure respect for the rule of law. ${ }^{114}$

Advocate General Øe's Opinion was published on $29^{\text {th }}$ November $2018^{115}$ The Advocate General after quickly finding the case admissible, and not in conformity with the free movement of capital under Article 63 TFEU, ${ }^{116}$ extensively analysed whether there can be an independent finding of an infringement based on the Charter, in this case Article 17 thereof. ${ }^{117}$ The Advocate General applied a narrow interpretation of the ERT jurisprudence and therefore disagrees with the commission. ${ }^{118}$ In his view, the ERT jurisprudence, allows the CJEU to examine fundamental rights when determining whether a Member State is entitled to make a derogation from the freedoms of movement, thus when fundamental rights are used as a shield and the issue therefore fall within the scope of EU law in their functional dimension. ${ }^{119}$ In contrast what the Commission is asking would allow, in his view, the CJEU to review national legislation if there exists a restriction of freedoms of movement, thus opening a gateway to the scope of the Charter for the CJEU to rule independently on the compatibility of the national legislation concerned with each of the fundamental rights,

${ }^{108}$ European Commission, 'Free movement of capital: Commission refers Hungary to the Court of Justice of the EU for failing to comply with EU rules on the rights of cross-border investors in agricultural land' (n 105).

109 Commission v Hungary (n 21).

110 Joined Cases C-52/16 and C-113/16 SEGRO’ Kft v Vas Megyei Kormányhivatal Sárvári Járási Földhivatala and Günther Horváth v V as Megyei KormányhivatalEU:C:2018:157.

111 ibid, paras 127-129.

112 Commission v Hungary (n 21), Opinion of AG ØE, para 3.

113 ibid, para 99.

114 ibid, para 99; SEGRO (n 110).

115 Opinion of AG ØE (n 112), para 3.

116 ibid, para 48-54.

117 ibid, para 56.

118 ibid, para 91

119 ibid, paras 97-98. 
which would be an extension of the ERT jurisprudence. ${ }^{120}$ In the alternative, the Advocate General further proposed that a separate examination of Article 17 of the Charter lacks relevance. ${ }^{121}$ In the further alternative, the Advocate General held, that Paragraph 108(1) of the 2013 Law on transitional arrangements is incompatible with Article 17(1) of the Charter. ${ }^{122}$ Thus the Advocate General proposed the Court to declare that Hungary has failed to fulfil its obligations under Article 63 TFEU and to dismiss the other aspects of the action, as for him the application of the Charter is subsumed by the application of the provisions on free movement of capital. ${ }^{123}$

The CJEU sitting in Grand Chamber found in its judgement in C-235/17 Commission $v$ Hungary, that by adopting Paragraph 108(1) of the 2013 Law on transitional measures and thereby cancelling usufructuary rights previously created over agricultural land in Hungary, as between persons who are not close members of the same family, Hungary has failed to fulfil its obligations, arising from the principle of the free movement of capital under Article 63 TFEU and the right to property guaranteed by Article 17 of the Charter. ${ }^{124}$

Similar to the Advocate General the CJEU found the case to be admissible and that the conformity of the law does not need to be considered in regard to the freedom of establishment under Article 49 TFEU, as it is inextricably linked to the freedom of capital under Article 63 TFEU. ${ }^{125}$ In contrast to the Advocate General the CJEU, however, continued by first analysing the applicability of Article 63 TFEU and thus the existence of a restriction of the movement of capital before subsequently considering whether the restriction of the free movement of capital is justified and whether Article 17 of the Charter is applicable. ${ }^{126}$ In regard to whether Article 17 of the Charter is applicable, the CJEU first recalled with reference to Akerberg Fransson that: 'the fundamental rights guaranteed by the Charter are applicable in all situations governed by EU law and that they must, therefore, be complied with inter alia where national legislation falls within the scope of EU law'. ${ }^{127}$ The CJEU next reiterated that national legislation falls within the scope of EU law also where a Member State wishes to justify, on grounds envisaged in Article 65 TFEU, a derogation from a fundamental freedom. ${ }^{128}$ The CJEU concluded therefrom, that where a Member State, just like Hungary in this case, seeks to justify a restriction of one or more freedoms of movement, 'the compatibility of the contested provision with EU law must be examined in the light both of the exceptions thus provided for by the Treaty and the Court's case-law, on the one hand, and of the fundamental rights guaranteed by the Charter, on the other hand'. ${ }^{29}$ In the remaining judgment, the CJEU finds that the cancellation of usufructuary rights constitutes a deprivation of property within the meaning of Article 17 of the Charter, and further that this deprivation of property cannot be justified in the absence of a public-interest ground and of any arrangements for compensation. ${ }^{130}$

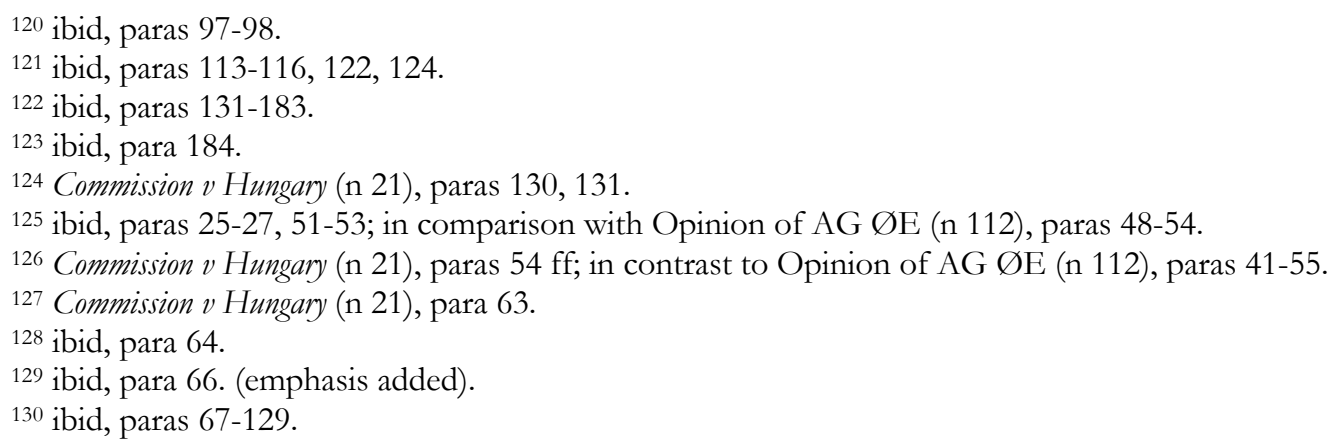




\subsection{The Relevance of C-235/17 COMmission v Hungary FOR AN EFFECTIVE RULE OF}

\section{LAW ENFORCEMENT}

While this judgement of the Court, in contrast to the judgement in C-619/18 Commission v Poland, might not necessarily be featured in the next EU textbooks, it is nevertheless relevant for an effective rule of law enforcement by the Commission. Thus, the most significant aspects of the judgement as well as what has been missed by the CJEU in order to protect the values of the Union shall be highlighted.

First, the importance of the fact that the action is admissible, shall be highlighted, as this not only confirms, that the Commission can bring an action for a declaration that a Member State has failed to fulfil an obligation under Article 258 TFEU based solely on the rights guaranteed in the Charter, but also that the Commission is now willing to bring such requests. ${ }^{131}$ While almost ten years have passed since the Lisbon Treaty has entered into force and changed the legal status of the Charter, making it legally binding primary law (Article 6(1) TEU) which can be invoked not only by the EU institutions but also by individuals, the Commission so far had refrained from bringing actions under Article 258 TFEU based solely on the Charter against Member States. ${ }^{132}$ Even though it has always declared that it is competent to do so. ${ }^{133}$ Thus, the fact that the Commission has asked the CJEU for the first time in case C-235/17 Commission v Hungary, and in subsequent cases C-66/18 Commission v Hungary, and C-78/18 Commission v Hungary, to find that a Member State is breaching not only the freedoms of movement but in an independent assessment, to determine that the Member State is also breaching the Charter shows that the Commission takes respect for fundamental rights and consequently the rule of law seriously. ${ }^{134}$

Second, it is significant that the CJEU followed the request of the Commission to assess, under an infringement procedure, the compatibility of a national legislation with the Charter separately from the compatibility with a freedom of movement. ${ }^{135}$ Thus, the CJEU has taken another step towards more fundamental rights protection in Europe and thereby ensured that the Charter can become a significant legal instrument in the Commission's infringement policy and its enforcement of fundamental rights. In order to achieve this result, the CJEU applied a broad interpretation of the ERT jurisprudence, in contrast to the Advocate General. ${ }^{136}$ Unfortunately, the CJEU has not given many reasons for applying the Charter in this instance other than restating its previous case law in Akerberg Fransson and ERT. ${ }^{137}$ While it is precisely these judgments that justify a broad application of the Charter, ${ }^{138}$

\footnotetext{
131 Opinion of AG ØE (n 112), para 66; Frank Hoffmeister, 'Enforcing the EU Charter of Fundamental Rights in Member States : How Far are Rome, Budapest and Bucharest from Brussels?' in Armin von Bogdandy and Pál Sonnevend (eds), Constitutional Crisis in the European Constitutional Area: Theory, Law and Politics in Hungary and Romania (1 edn, Hart/Beck 2015) 200.

132 Adam Lazowski, 'Decoding a Legal Enigma: The Charter of Fundamental Rights of the European Union and infringement proceedings' (2013) 14 ERA Forum 573 573-574.

133 European Commission, '2010 Report on the Application of the EU Charter of Fundamental Rights (Report)' (COM(2011) 160 final 30 March 2011) 4.

134 Opinion of AG ØE (n 112), para 99.

135 Commission v Hungary (n 21), paras $59 \mathrm{ff}$.

136 ibid, paras 63-66.

${ }_{137}$ Commission v Hungary (n 21), paras 63-66; Opinion of AG ØE (n 112), paras 77 ff.

138 See in this regard: Case C-390/12 Robert Pfleger, Autoart as, Mladen Vucicevic, Maroxx Software GmbH, Ing.

Hans-Jörg Zehetner EU:C:2013:747, Opinion of AG Sharpston, paras 63-70; C-390/12 Robert Pfleger, Autoart as,
} 
the issue surrounding the uncertainty associated with the scope of application under Article 51 of the Charter, which is crucial for its application, to use the words of Lazowski, still 'amount to a risky round of poker'. ${ }^{139}$ This uncertainty about Article 51 of the Charter can therefore still be an issue in the future, as the Commission usually brings infringement proceedings in cases where it is likely to win, in order not to put its legitimacy at risk. ${ }^{140}$

Third, even though the court found not only an infringement based on the freedom of capital but also on Article 17 of the Charter, the Court missed the point why this separate assessment would have been so important. The significance was not with the secondary issue of property rights, but on the arbitrary exercise of power of the State (arbitrary removing of property rights) which adversely affects the core meaning of the rule of law, as it breaches the principles of legal certainty and legality. ${ }^{141}$ Thus the CJEU failed to apply a systemic approach of the rule of law, which would not only have been in line with its previous judgements in Portuguese Judges and C-619/18 Commission v Poland, ${ }^{142}$ but also would have allowed the CJEU to address its concerns on the rule of law (in other areas than the judicial independence) directly. The CJEU could thus have applied a strong rule of law didactic in this case, in order to strengthen its credibility showing that fundamental rights, the rule of law and democracy are not only empty phrases but that the Union actively 'contributes to the preservation and to the development of these common values. ${ }^{143}$ Highlighting the triangular relationship between fundamental rights, the rule of law and democracy, ${ }^{144}$ meaning that there cannot be respect for the rule of law and democracy without respect for fundamental rights. ${ }^{145}$ In consequence, this case had the potential to not only enhance fundamental rights protection in the EU legal order but also to make the Charter a valuable tool for the Commission to enforce the values enshrined in Article 2 TEU including the rule of law.

\subsection{WHAT THE CJEU CAN LEARN FROM THIS CASE IN THE RULE OF LAW CRISIS}

The Commission has shown a high level of political will by insisting that the CJEU should not only consider the question of a breach of a fundamental freedom but also to engage with the question whether the Charter is applicable and a fundamental right breached as well as the rule of law, thus shifting the focus from the Economic Union to the Union of values. ${ }^{146}$ This approach is remarkable as it provides new solutions to overcome challenges encountered during the past years in the rule of law enforcement as it allows the CJEU to

Mladen Vucicevic, Maroxx Software GmbH, Hans-Jörg Zehetner EU:C:2014:281, paras 57-60; SEGRO (n 110), Opinion of AG ØE EU:C:2017:410, para 141.

139 Lazowski (n 132) 581-582.

140 Lazowski (n 132) 585; Blauberger and Kelemen (n 8) 323.

${ }^{141}$ Lisa M. Austin, 'Property and the rule of law' (2014) 20 Legal Theory 79 especially 83-84; Groussot and Lindholm (n 37) 29.

142 See in this regard Groussot and Lindholm (n 37) 29.

${ }^{143}$ In allusion to the preample of the Charter of Fundamental Rights of the European Union [2012] OJ C 326/02.

${ }^{144}$ Laurent Pech and others, 'An EU mechanism on democracy, the rule of law and fundamental rights Annex I -An EU mechanism on democracy, the rule of law and fundamental rights' (European Parliamentary Research Service April 2016) 22.

145 European Commission, 'A new EU Framework to strengthen the Rule of Law (Communication)' (n 22) 4; Joined Cases C-402/05 P and C-415/05 P Yassin Abdullah Kadi and Al Barakaat International Foundation v Council of the European Union EU:C:2008:461, para 316; Stafford v United Kingdom App no. 46295/99 (ECtHR, 28 May 2001), para 63.

146 Opinion of AG ØE (n 112), paras 64, 99. 
address concerns with the rule of law through concerns with fundamental rights. While this is the first time that the Commission has pursued such an approach, it will not be the last, as the Commission has already brought two more cases adopting the same approach. ${ }^{147}$ The CJEU should thus follow the argumentation of the Commission in the next case. If the CJEU would apply a strong rule of law didactic and a systemic approach to the rule of law, the infringement procedure can deploy its full strength in the fight against measures breaching the rule of law that lie outside the independence of the judiciary. Such an approach can thus provide for an effective infringement procedure even where a measure breaches the rule of law. The Commission and the CJEU should thus continue to apply creative, but wellbalanced approaches to the infringement procedure such as the one identified here as well as the approach identified in the previous chapter; in order for Article 258 TFEU to remain an effective measure even in times of the rule of law crisis.

To conclude, this case has provided the Commission with a significant legal instrument that can be used to address and enforce breaches of fundamental rights: The Charter. This enhances not only the importance of fundamental rights in the EU legal order but also make it a valuable tool for the Commission to enforce the values enshrined in Article 2 TEU. The case at hand already provides a step in the right direction as it has strengthening fundamental right protection and thereby strengthened the rule of law. Since this is the first of a series of actions that the Commission has launched, ${ }^{148}$ it is hoped that the CJEU adhere to its previous systemic approach to the rule of law thus continuing to make the rule of law more visible, legitimate and enforceable.

\section{CONCLUSION}

Despite the effectiveness of the infringement procedure in thousands of cases, the procedure and the approach of the Commission has been subject to much criticism over the past years, as it was held to be ineffective when dealing with breaches of the rule of law, fundamental rights and other values enshrined in Article 2 TEU. ${ }^{149}$

However, case C-619/18 Commission v Poland, which has been analysed in the second chapter exemplified, how the Commission could use infringement proceedings effectively to protect the national judiciary and thus ensure the separation of powers, which is essential for the rule of law. ${ }^{150}$ The judgement is ground-breaking for the enforcement of the rule of law in many reasons, for one as it clarified that the Commission can bring infringement proceedings under Article 258 TFEU even where Article 7(1) TEU has been initiated, second that Article 19(1)(2) TEU creates an obligation on Member States to provide an effective judicial protection which can be enforced through infringement proceedings and third that the organisation of the national judiciary is not a purely domestic matter which the Commission and the CJEU are eager to protect. In order to safeguard the national judiciary in the rule of law crisis it was found that a combined approach, of expedited procedure,

\footnotetext{
${ }^{147}$ See in this regard Case C-66/18 European Commission v Hungary, Action brought on 1 February 2018; Case C-78/18 European Commission v Hungary, Action brought on 1 June 2018.

148 ibid.

149 Blauberger and Kelemen (n 8) 323.

150 On the importance of the Role of Courts for the rule of law and democracy see Susanne Baer, 'The Rule of — and not by any_Law. On Constitutionalism' (2018) 71 Current Legal Problems 335 358-360.
} 
interim measures in combination with Article 19(1)(2) TEU is necessary. This approach is thus making the infringement procedure effective in the 'rule of law crisis' where the judiciary is under attack.

Moreover, case C-235/17 Commission v Hungary exemplified, how the Commission is determined to transform the Charter into a, possibly, significant legal instrument in the Commission's infringement policy and the rule of law crisis. The CJEU, by ruling that the Charter can be a sole ground for finding that a Member State has failed to fulfil its obligations under the Treaties, enables the Commission to achieve this result by making fundamental rights, which are a valuable component of the rule of law, more visible, legitimate and enforceable. Nevertheless, the CJEU failed to address the concerns of the arbitrary exercise of power and thus with the rule of law directly. Thus, this case differs from C-619/18 Commission v Poland in the way that there is no strong rule of law didactic. If the CJEU would have applied a strong rule of law didactic as well as finding that the Charter can be a sole ground for an infringement by a Member State, this could have further enhanced rule of law enforcement as well as maintained the credibility of the EU as it demonstrates that fundamental rights, the rule of law and democracy are not only empty phrases but that the EU actively 'contributes to the preservation and to the development of these common values ${ }^{151}$.

To conclude, it was shown that, on the one hand, the Commission should be able to address the most controversial provisions of Hungary and Poland regarding the judiciary through the infringement procedure (as exemplified by C-619/18 Commission v Poland), and that on the other hand the Charter could become a significant legal instrument in the Commission's infringement policy towards Member States that are undermining fundamental rights and the rule of law (as exemplified by C-235/17 Commission v Hungary). Therefore, the infringement procedure is and remains an effective enforcement mechanism which provides a solution to existing problems, even in the 'rule of law crisis'. But its effectiveness depends more than ever on the Commission's willingness to continue bringing unprecedented proceedings and the CJEU's ability to give well-balanced and legally wellfounded judgements.

${ }^{151}$ In allusion to the preample of the Charter of Fundamental Rights of the European Union [2012] OJ C 326/02. 


\section{LIST OF REFERENCES}

Austin LM, 'Property and the rule of law' (2014) 20 Legal Theory 79

DOI: https://doi.org/10.1017/S1352325214000056

Baer S, 'The Rule of — and not by any_Law. On Constitutionalism' (2018) 71 Current Legal Problems 335

DOI: https://doi.org/10.1093/clp/cuy010

Bárd P and others, An EU mechanism on democracy, the rule of law and fundamental rights Annex II - Assessing the need and possibilities for the establishment of an EU scoreboard on democracy, the rule of law and fundamental rights (European Parliamentary Research Service, 2016)

DOI: $\underline{\text { https://doi.org/10.2861/21456 }}$

Blauberger M and Kelemen RD, 'Can courts rescue national democracy? Judicial safeguards against democratic backsliding in the EU’ (2017) 24 Journal of European Public Policy 321 DOI: https://doi.org/10.1080/13501763.2016.1229357

Bonelli M and Claes M, 'Judicial serendipity: how Portuguese judges came to the rescue of the Polish judiciary: ECJ 27 February 2018, Case C-64/16, Associação Sindical dos Juízes Portugueses' (2018) 14 European Constitutional Law Review 622

DOI: https://doi.org/10.1017/S1574019618000330

Canor I, 'My brother's keeper? Horizontal solange: “An ever closer distrust among the peoples of Europe”" (2013) 50 Common Market Law Review 383

Closa C, Kochenov D and Weiler JHH, 'Reinforcing Rule of Law Oversight in the European Union’ (2014) 25 Robert Schuman Centre for Advanced Studies Research Paper

Grabbe H, 'Six Lessons of Enlargement Ten Years On: The EU's Transformative Power in Retrospect and Prospect' (2014) 52 JCMS: Journal of Common Market Studies 40

DOI: https://doi.org/10.1111/jcms.12174

Groussot X and Lindholm J, 'General Principles: Taking Rights Seriously and Waving the Rule-of-Law Stick in the European Union' in Katja Ziegleret al, (ed), Constructing Legal Orders in Europe: General Principles of EU Law (Edward Elgar, Forthcoming 2019)

Hillion C, 'Overseeing the Rule of Law in the EU: Legal Mandate and Means' in Closa C and Kochenov D (eds), Reinforcing rule of law oversight in the European Union (Cambridge University Press 2016)

DOI: https://doi.org/10.1017/CBO9781316258774.005 
Hoffmeister F, 'Enforcing the EU Charter of Fundamental Rights in Member States : How Far are Rome, Budapest and Bucharest from Brussels?' in Von Bogdandy A and Sonnevend P (eds), Constitutional Crisis in the European Constitutional Area : Theory, Law and Politics in Hungary and Romania (1 st edn, Hart/Beck 2015)

DOI: https://doi.org/10.5771/9783845261386-204

Jakab A, 'Application of the EU CFR by National Courts in Purely Domestic Cases' in Jakab A and Kochenov D (eds), The Enforcement of EU Law and Values: Ensuring Member States' Compliance (1 edn, Oxford University Press 2017)

DOI: https://doi.org/10.1093/acprof:oso/9780198746560.003.0015

Kochenov D, 'On Policing Article 2 TEU Compliance - Reverse Solange and Systemic Infringements Analyzed' (2013) 33 Polish Yearbook of International Law 145

Kochenov D, 'Biting Intergovernmentalism: The Case for the Reinvention of Article 259 TFEU to Make It a Viable Rule of Law Enforcement Tool' (2015) 7 Hague Journal on the Rule of Law 153

DOI: https://doi.org/10.1007/s40803-015-0019-1

Kochenov D and Pech L, 'Upholding the Rule of Law in the EU: On the Commission's 'PreArticle 7 Procedure' as a Timid Step in the Right Direction' (2015) 24 Robert Schuman Centre for Advanced Studies Research Paper 512

Kochenov D and Pech L, 'Monitoring and Enforcement of the Rule of Law in the EU: Rhetoric and Reality' (2015) 11 European Constitutional Law Review 512

DOI: https://doi.org/10.1017/S1574019615000358

Kochenov D and Pech L, 'Better Late than Never? On the Commission's Rule of Law Framework and its First Activation' (2016) 54 Journal of Common Market Studies 1062 DOI: https://doi.org/10.1111/jcms.12401

Konchev D and Klamert M, 'Article 2 TEU' in Kellerbauer M, Klamert M and Tomkin J (eds), The Treaties and the Charter of Fundamental Rights - A Commentary (Oxford University Press 2019)

Krajewski M, 'Associação Sindical dos Juízes Portugueses: The Court of Justice and Athena's Dilemma' (2018) 3 European Papers 395

DOI: https://doi.org/10.15166/2499-8249/218

Lazowski A, 'Decoding a Legal Enigma: The Charter of Fundamental Rights of the European Union and infringement proceedings' (2013) 14 ERA Forum 573

DOI: https://doi.org/10.1007/s12027-013-0331-y

Müller JW, 'Should the EU Protect Democracy and the Rule of Law inside Member States?' (2015) 21 European Law Journal 141 
Pech L and Platon S, 'A. Court of Justice: Judicial independence under threat: The Court of Justice to the rescue in the ASJP case' (2018) 55 Common Market Law Review 1827

Pech L et al, An EU mechanism on democracy, the rule of law and fundamental rights Annex I - An EU mechanism on democracy, the rule of law and fundamental rights (European Parliamentary Research Service April 2016)

DOI: https://doi.org/10.2861/647142

Penn W, Some fruits of solitude, in reflections and maxims relating to the conduct of human life (2nd edn, Printed at London; and re-printed at Edinburgh, 1694)

Scheppele KL, 'Enforcing the Basic Principles of EU Law Through Systemic Infringement Actions' in Closa C and Kochenov D (eds), Reinforcing Rule of Law Oversight in the European Union (Cambridge University Press 2016)

DOI: https://doi.org/10.1017/CBO9781316258774.007

Schmidt $\mathrm{M}$ and Bogdanowicz $\mathrm{P}$, 'The infringement procedure in the rule of law crisis: How to make effective use of Article 258 TFEU' (2018) 55 Common Market Law Review 1061

Toggenburg GN and Grimheden J, 'Upholding Shared Values in the EU: What Role forthe EU Agency for Fundamental Rights?’ (2016) 54 Journal of Common Market Studies 1093 DOI: https://doi.org/10.1111/jcms.12404

Von Bogdandy A and others, 'Reverse Solange-Protecting the Essence of Fundamental Rights against EU Member States' (2012) 49 Common Market Law Review 489

Von Danwitz T, 'The Rule of Law in the Recent Jurisprudence of the ECJ' in Schroeder W (ed), Strengthening the Rule of Law in Europe: From a Common Concept to Mechanisms of Implementation(1st edn, Hart Publishing, 2016)

DOI: https://www.doi.org/10.5040/9781474202534.ch-009 